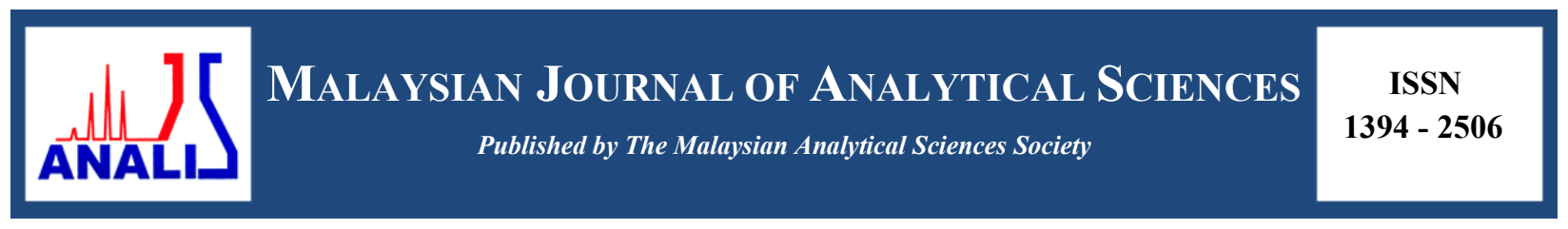

\title{
INCORPORATION OF GRAPHENE INTO COUNTER ELECTRODE TO ENHANCE THE PERFORMANCE OF DYE-SENSITIZED SOLAR CELLS
}

\author{
(Pengabungan Grafin dalam Elektrod Lawan untuk Meningkatkan Prestasi Sel Suria Terpeka \\ Pewarna)
}

\author{
Aisyah Bolhan and Norasikin Ahmad Ludin* \\ Solar Energy Research Institute (SERI) \\ Universiti Kebangsaan Malaysia, 43600 UKM Bangi, Selangor, Malaysia \\ *Corresponding author: sheekeen@ukm.edu.my
}

Received: 12 April 2017; Accepted: 1 September 2017

\begin{abstract}
Platinum $(\mathrm{Pt})$ is a conventional material for counter electrodes of dye-sensitized solar cells (DSSCs) due to its excellent electrocatalytic activity in the redox process. However, the high cost of Pt motivates researchers to search for composite materials of Pt to reduce its consumption. This study is aimed to reduce Pt usage by incorporating reduced graphene oxide (rGO) with Pt of different ratios in counter electrode thin films and to determine the optimum ratio with the highest efficiency. A DSSCbased platinum/rGO (Pt/rGO) counter electrode composite was fabricated using doctor-blade method. X-ray diffraction analysis was performed to examine the crystallite structure of the Pt/rGO thin film. The optimum ratio was found to be 70:30 of Pt:rGO, with current-voltage characterization showing an efficiency of $5.5 \%$, open-circuit voltage of $0.739 \mathrm{~V}$, current density of 12.5 $\mathrm{mA} / \mathrm{cm}^{2}$, and fill factor of $59.24 \%$.
\end{abstract}

Keywords: counter electrode, dye-sensitized solar cell, graphene, platinum, thin film

Abstrak

Platinum (Pt) adalah bahan konvensional untuk elektrod lawan sel suria terpeka pewarna (DSSC) memandangkan ia mempunyai aktiviti pemangkinan-elektro dalam proses redoks yang sangat baik. Namun begitu, harga Pt sangat mahal mendorong para pengkaji untuk mencari bahan komposit Pt yang boleh mengurangkan penggunaannya. Kajian ini menumpukan pengurangan penggunaan Pt dengan menggabungkannya dengan grafin oksida terturun (rGO) dengan Pt dalam filem nipis elektrod lawan pada nisbah berbeza dan untuk menentukan nisbah paling optimum yang meningkatkan kecekapan. DSSC berasaskan komposit elektrod lawan platinum/grafin oksida (Pt/rGO) telah difabrikasikan menggunakan kaedah doctor blade. Analisis Pembelauan sinar-X (XRD) telah dijalankan untuk memeriksa struktur kristal pada filem nipis Pt/rGO. Nisbah optimum yang dicapai adalah 70:30 kepada Pt:rGO dimana pencirian arus-voltan (I-V) menunjukkan nilai kecekapan ialah 5.5\%, dengan nilai litar voltan terbuka $V_{\text {oc }}$, ketumpatan arus $J_{\text {sc, }}$ dan faktor mengisi $F F$, masing-masing dengan nilai $0.739 \mathrm{~V}, 12.5 \mathrm{~mA} / \mathrm{cm}^{2}$ dan $59.24 \%$.

Kata kunci: elektrod lawan, sel suria terpeka pewarna, grafin, platinum, filem nipis

\section{Introduction}

Over the past decade, green and renewable energy sources have been explored and used [1] to reduce $\mathrm{CO}_{2}$ emissions [1-3]. Several types of renewable energy include hydro, wind, and solar or photovoltaic (PV). Among these sources, PV is the third most valued energy source that leads to the intense development of PV cell technology in recent years [1]. The sun is the best source of energy among the renewable or non-renewable energy because it provides $174,000 \mathrm{TW}$ per year to the earth [4]. In other words, the energy from the sun should be utilized optimally. Ongoing 
intense research is currently still being conducted for PV energy sources. Currently, PV energy sources have three generations of solar cell. The first generation is the silicon solar cell, in which the power conversion efficiency achieved 25\% [5]. Presently, the silicon solar cell has dominated the market, but the high production cost has limited the spread of cell application. The second generation is the compound solar cell, in which gallium arsenide reached 28\% [6] efficiency and cadmium telluride attained 20\% [6, 7]. However, similarly the second generation also bears a high cost of production, which leads to the third generation. The third generation consists of dyesensitized solar cells (DSSCs), organic solar cell, and quantum dots solar cells [8]. Third generation cells have lower cost production than conventional solar cell and have green technology that minimizes the environmental effect.

DSSC is one of the third generations of PV devices that gained the attention from most researchers. DSSC has several important parts that make up the cells; these parts include the titanium dioxide $\left(\mathrm{TiO}_{2}\right)$ photoanode, which helps excite the electron to the covalent bond; platinum $(\mathrm{Pt})$ counter electrode, which acts as a catalyst in redox process; ruthenium dye (N719), which acts as a sensitizer that absorbs photon from light; and iodide electrolyte, which helps transfer the electron between two electrodes and also works in the redox process $[9,10]$. Pt is a catalyst material that helps in reducing the triiodide ions into an iodide ion at counter electrode and electrolyte interface [11]. A faster rate of reducing the triiodide ions results in fast electron charge transfer. However, $\mathrm{Pt}$ is corrosive toward iodide electrolyte and is commercially expensive [12]. Therefore, replacing Pt with other materials or reducing $\mathrm{Pt}$ consumption using Pt composite materials is crucial. In addition, it is necessary to find the material that has a high electrocatalytic activity compared with Pt.

Recently, graphene has attracted much attention as a counter electrode material because of its electrical properties, corrosive resistance, low cost, and abundance [13]. The rGO structure is a three-dimensional network and has an oxygen-containing functional group that contributes to the electrocatalytic activity of rGO counter electrode [14]. Graphene is considered as a promising composite material with Pt. Hence, several ratios of composite Pt/rGO thin films were prepared in the starting ratio of the weight of the Pt to rGO 99:1 as the first ratio. The ratio of the rGO and the Pt will continuously increase and decrease, respectively. This paper focuses on determining the optimum ratio of rGO that can be incorporated into the Pt-based DSSC while reducing the use of Pt to achieve higher efficiency than Pt-based DSSC.

\section{Materials}

\section{Materials and Methods}

$\mathrm{TiO}_{2}$ (WER2-0, Solaronix) was used as photoanode thin film, platinum paste PT-1 was purchased from DyesolAustralia, and rGO-B026 purchased from graphenea were used as the counter electrode thin films. The N719 ruthenium dye sensitizer purchased from Dyesol were diluted with ethanol to form $0.3 \mathrm{mM}$ solution mixture. Iodide electrolyte (Iodolyte, AN-50) performed as an electrolyte. An $8 \Omega \mathrm{cm}^{-2}$ FTO glass substrate (FTO Tec 8, Dyesol) and $15 \Omega \mathrm{cm}^{-2}$ FTO thin film (FTO Tec 15, Dyesol) will function as a counter electrode and photoanode glass substrate, respectively. Surlyn (Meltonix) is an adhesive material that helps photoanode and counter electrode glass substrate to attach together.

\section{Preparation of the counter electrode thin films}

$\mathrm{Pt} / \mathrm{rGO} \mathrm{CE}$ thin films were prepared with commercially available Pt paste and $\mathrm{rGO}$ powder. The $\mathrm{Pt} / \mathrm{rGO}$ thin films were prepared as the ratio of the weight of Pt to rGO are 99:1, 95:5, 90:10, 85:15, 80:20, 75:25, 70:30, and 65:35. The Pt paste and rGO powder were ultrasonicated by the ultrasonic bath for approximately 15 minutes to create homogeneous composite mixture. Then, the mixture was stirred for another 15 minutes using the magnetic stirring bar and pasted onto the glass substrate of the $1.5 \mathrm{~cm} \times 2 \mathrm{~cm}, 8 \Omega \mathrm{cm}^{-2}$ fluorine-doped tin oxide (FTO) using doctorblade method. Pt/rGO CE thin films were annealed for 30 minutes at $450{ }^{\circ} \mathrm{C}$.

\section{Fabrication of the DSSC}

$\mathrm{TiO}_{2}$ photoanode thin films were also prepared using the doctor-blade method, and the thin films were then immersed in the N719 ruthenium dye for $16 \mathrm{~h}$ with an active area of $0.25 \mathrm{~cm}^{2}$. The photoanode and counter electrode were attached together by using a warm press machine to melt the Surlyn placed between the two electrodes. The active area part was injected with iodide electrolyte through the aperture between the electrodes. Then, the aperture was sealed to complete the fabrication of DSSC. 


\section{$\mathrm{X}$-ray diffraction analysis}

\section{Results and Discussion}

The X-ray diffraction (XRD) pattern of Pt, composite Pt/rGO of different ratio, and rGO are illustrated in Figure 1. Pt has been observed to have a prominent peak at (111) plane attributed to $39.8^{\circ}$ with JCPDS of 03-065-2868. The Pt peak decrease until ratio 90:10 and rise slightly at ratio 85:15 before decreasing again at ratio 80:20 as the weight ratio of rGO increases. rGO has a weak intensity, shown in J of Figure 1, where the $h k l$ plane of (006) attribute to $26.6^{\circ}$ with JCPDS of $00-026-1076 . \mathrm{SnO}_{2}$ diffraction angle is $26.5^{\circ}$, which is close to the rGO at (110) plane. The presence of Pt has concealed the rGO peak when Pt is mixed with the rGO. This process resulted in no visible rGO peak for the XRD pattern of Pt/rGO CE thin film. Thus, Pt is more crystallized than rGO. The crystallite size for each CE thin film can be calculated using Debye-Scherrer equation as in (1) [15],

$$
D=\frac{0.9 \lambda}{\beta \cos \theta}
$$

where $D$ is the crystallite size, $\lambda$ is the wavelength, $\beta$ is the full width at the half maximum in radians, and $\theta$ is the diffraction angle. The crystallite sizes of the $\mathrm{CE}$ have been calculated, and the plotted graph is depicted in Figure 2 . From the graph, the crystallite size increase until ratio of Pt:rGO is 95:5 and the crystallite size began to fluctuate at the range $29-36 \mathrm{~nm}$ approximately until ratio of Pt:rGO is 75:25. The crystallite size continues to decrease again at the ratio of Pt:rGO 70:30 although the amount of rGO keeps increasing. The larger the size of crystallite leads to high surface roughness of the thin films. The higher surface roughness of the thin film contributes to large surface area that instigates the high conductivity of the counter electrode thin film. Thus, from Figure 2 we can determine that counter thin film of $\mathrm{Pt} / \mathrm{rGO}$ with ratio 80:20 has better conductivity among other due to large size of crystallite.

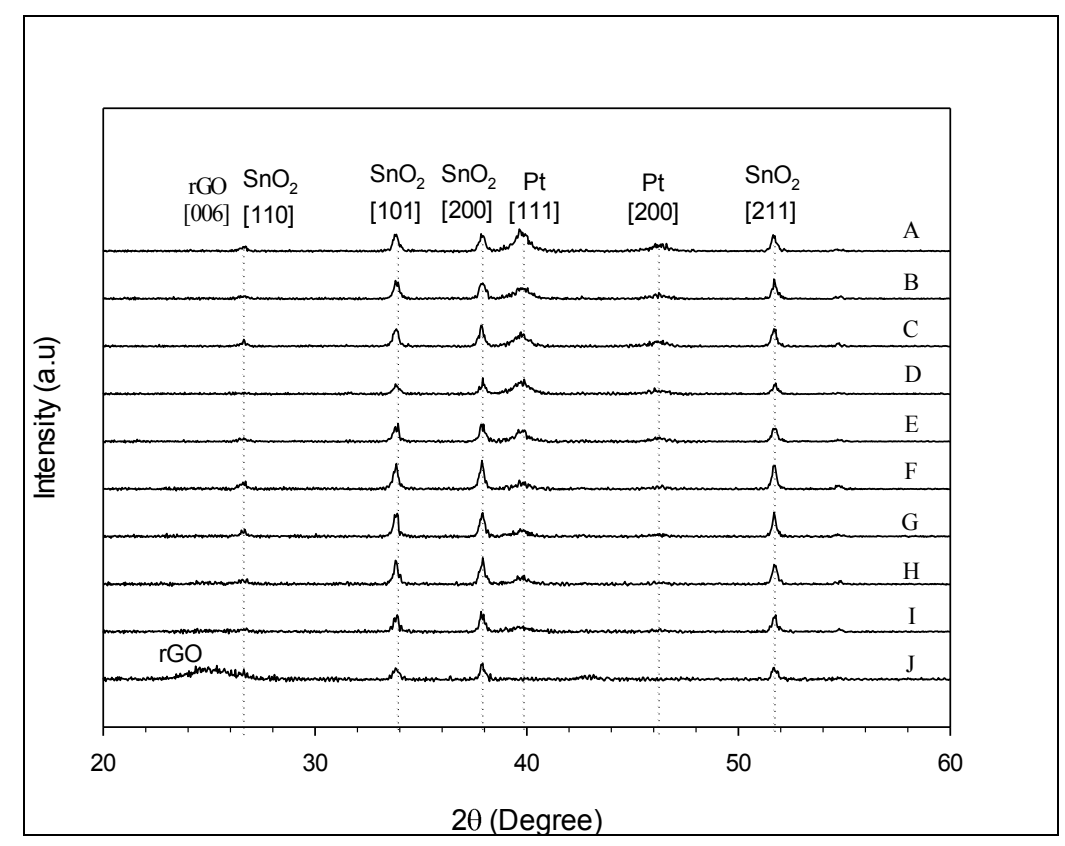

Figure 1. XRD of CE thin film. A is Pt. B-I is Pt:rGO with ratio 99:1, 95:5, 90:10, 85:15, 80:20, 75:25, 70:30, and $65: 35$. $\mathrm{J}$ is $\mathrm{rGO}$ 


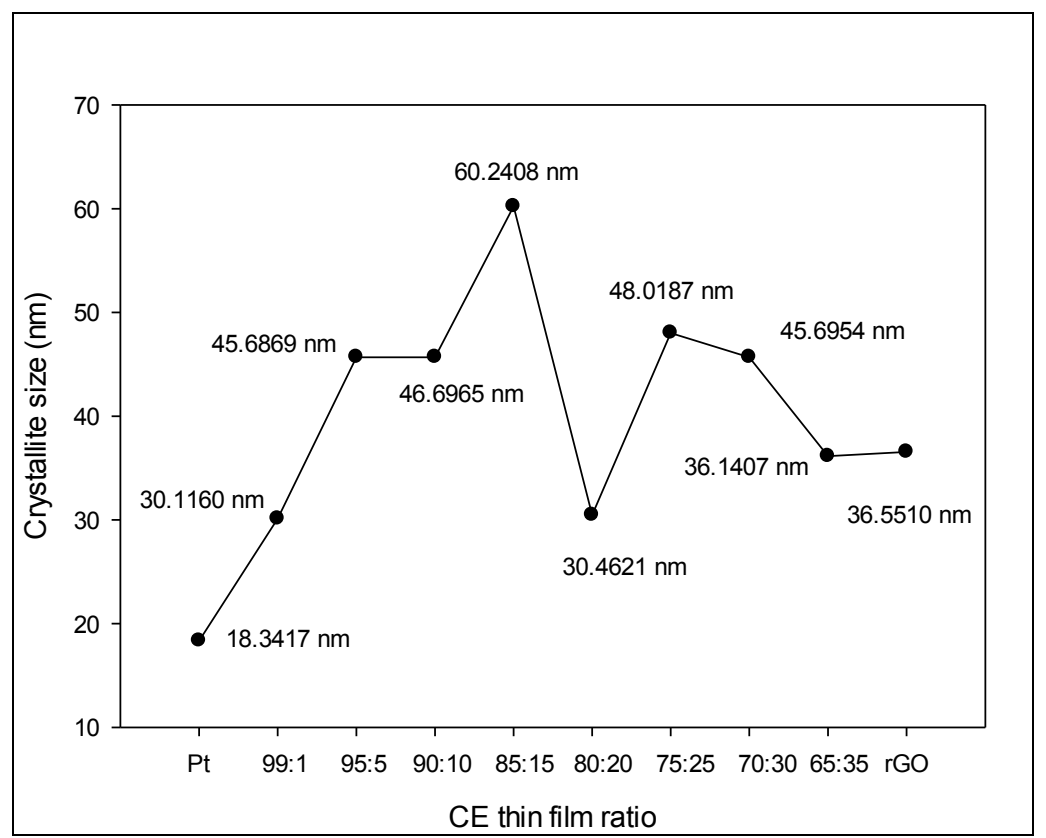

Figure 2. Crystallite size for Pt, rGO, and Pt:rGO at various ratios CE thin film

\section{Field emission scanning electron microscopy analysis}

The field emission scanning electron microscopy (FESEM) images of the thin films are used to study the morphology of the composite Pt:rGO counter electrode thin films (Figure 3). Pt is observed to have nano-like particle that spread homogeneously on the FTO glass substrate, and rGO is a nanosheet that has randomly aggregated. The three ratios of composite Pt/rGO thin films of the counter electrode are displayed in Figure 3 . The Pt:rGO of ratio 99:1 is the first ratio, where we can observe that Pt nanoparticles are more than the rGO nanosheets. The Pt nanoparticles decrease with the increase of the rGO, and the Pt:rGO of ratio 70:30 is the optimum ratio with higher efficiency. In ratio 70:30, the Pt nanoparticles were well blended in the rGO nanosheets. When the rGO increases, the Pt nanoparticle can no longer blend with the rGO nanosheets as presented in Figure 3. In ratio 65:35, we hardly observe the Pt nanoparticle and a small amount of rGO nanosheets attached to FTO glass substrate.
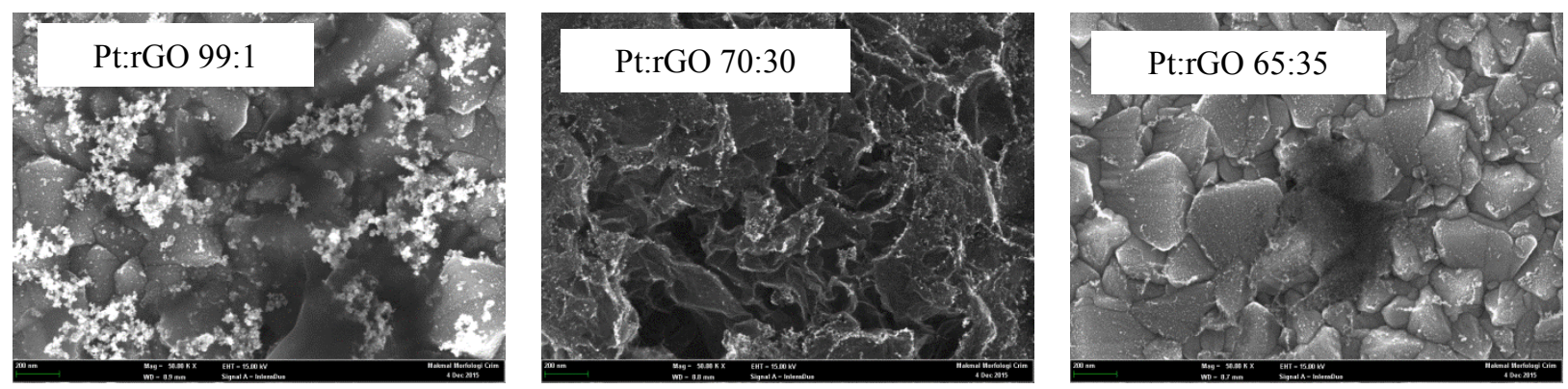

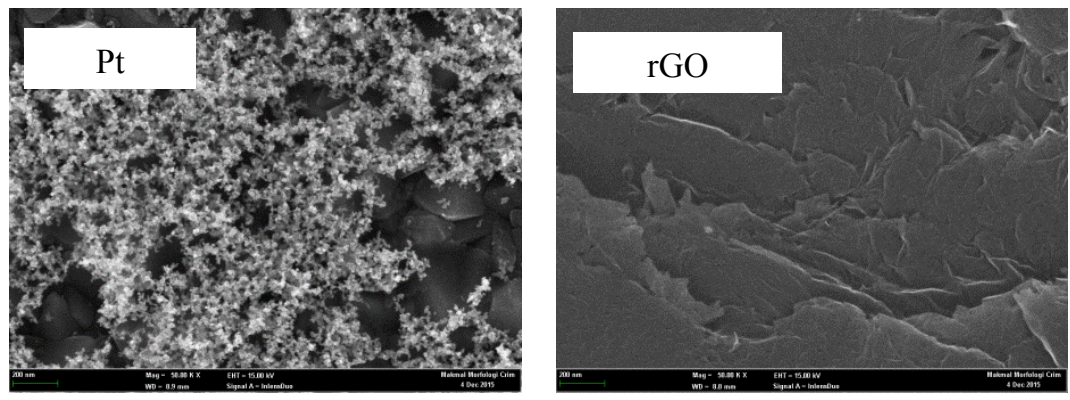

Figure 3. FESEM image of Pt, rGO, Pt:rGO of 99:1, 70:30, and 65:35

\section{Current-voltage analysis}

Figure 4 shows the current-voltage characterization for the DSSC with a different type of CE. The efficiency of the DSSC can be calculated by Martinson et al. [16] using equation 2:

$$
\eta=\frac{V o c J s c F F}{P i n}
$$

where $\eta$ is the efficiency of the device equals to the product of $V_{\mathrm{oc}}, J_{\mathrm{sc}}$, and FF divided by an $V_{\mathrm{oc}}$ of $100 \mathrm{~mW} / \mathrm{cm}^{2}$ under AM $1.5\left(P_{\text {in }}\right)$. The $I-V$ curve for rGO is the lowest with $J_{\text {sc }}$ of $8.40 \mathrm{~mA} / \mathrm{cm}^{2}$ and an $V_{\text {oc }}$ of $0.62 \mathrm{~V}$, resulting in poor efficiency of $1.97 \%$ as presented in Table 1 . It can be seen that the conductivity of the thin film increase as the value of $J_{\mathrm{sc}}$ increase following the increase of the amount of rGO. This is due to the rGO is more conductivity than $\mathrm{Pt}$, the adding of the rGO improves the conductivity of the thin films. The $I-V$ curve of $\mathrm{Pt} / \mathrm{rGO}$-based DSSC of ratio $70: 30$ shows high $J_{\mathrm{sc}}\left(12.50 \mathrm{~mA} / \mathrm{cm}^{2}\right)$ with $V_{\mathrm{oc}}$ of $0.74 \mathrm{~V}$, resulting in high efficiency of $5.5 \%$, which is better than Pt-based DSSC. Table 1 summarizes all the $I-V$ curve parameter of DSSC. Therefore, the addition of the rGO in CE thin film increases the efficiency of the DSSC until the ratio of Pt:rGO of 70:30. The efficiency decreases when more rGO is added. Thus, 70:30 is the optimum ratio of rGO that can be incorporated with $\mathrm{Pt}$ as a $\mathrm{CE}$ material.

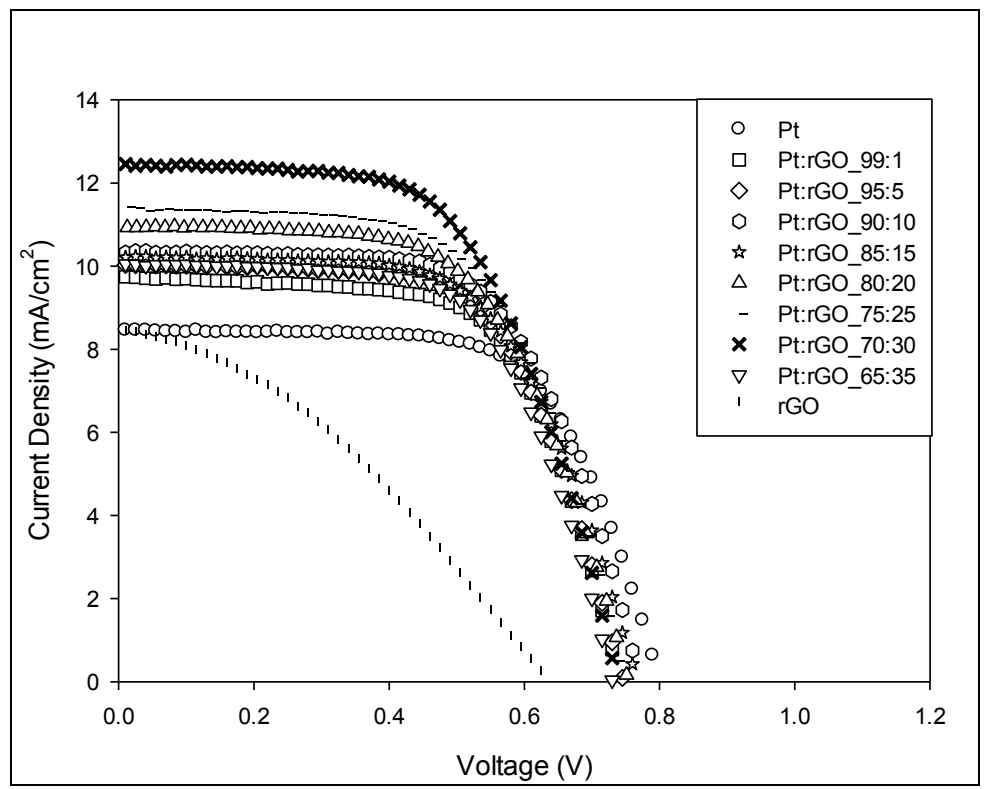

Figure 4. $I-V$ Characterization of DSSC 
Aisyah \& Norasikin: INCORPORATION OF GRAPHENE INTO COUNTER ELECTRODE TO ENHANCE

THE PERFORMANCE OF DYE-SENSITIZED SOLAR CELLS

Table 1. $I-V$ characterization parameter of DSSC with Pt CE, various ratio of Pt:rGO, and rGO

\begin{tabular}{lcccc}
\hline Counter electrode & $\boldsymbol{V}_{\text {oc }}(\mathbf{V})$ & $\boldsymbol{J}_{\text {sc }}\left(\mathbf{m A} / \mathbf{c m}^{2}\right)$ & $\boldsymbol{F F}(\mathbf{\%})$ & $\boldsymbol{\eta}(\mathbf{\%})$ \\
\hline rGO & 0.62 & 8.40 & 37.30 & 1.97 \\
Pt & 0.80 & 8.43 & 66.23 & 4.46 \\
Pt:rGO 99:1 & 0.74 & 9.73 & 64.59 & 4.67 \\
Pt:rGO 95:5 & 0.75 & 10.00 & 64.07 & 4.8 \\
Pt:rGO 90:10 & 0.77 & 10.30 & 63.55 & 5.10 \\
Pt:rGO 85:15 & 0.77 & 10.20 & 61.59 & 4.80 \\
Pt:rGO 80:20 & 0.75 & 10.90 & 60.66 & 5.00 \\
Pt:rGO 75:25 & 0.74 & 11.40 & 61.80 & 5.20 \\
Pt:rGO 70:30 & 0.74 & 12.50 & 59.24 & 5.50 \\
Pt:rGO 65:35 & 0.73 & 10.10 & 63.18 & 4.70 \\
\hline
\end{tabular}

\section{Conclusion}

The composite of $\mathrm{Pt} / \mathrm{rGO}$ counter electrode thin films with different ratios were successfully prepared using doctorblade method annealed at $450{ }^{\circ} \mathrm{C}$ for $30 \mathrm{~min}$. The ratio of $\mathrm{Pt} / \mathrm{rGO}$ that has been prepared were 99:1, 95:5, 90:10, $85: 15,80: 20,75: 25,70: 30$, and $65: 35$. The pattern of the increase and decrease of the efficiency of the DSSCs is observable after reaching the optimum ratio. $\mathrm{Pt}$ and $\mathrm{rGO} \mathrm{CE}$ thin film are also prepared using the same technique as references. The Pt/rGO of ratio 70:30 shows the highest efficiency of $5.5 \%$ with the $J_{\text {sc }}$ value of $12.50 \mathrm{~mA} / \mathrm{cm}^{2}, V_{\text {oc }}$ value of $0.74 \mathrm{~V}$, and FF is 59.24 . The Pt counter electrode-based DSSC incorporated with rGO has higher efficiency at an optimum ratio of 70:30 in comparison with the Pt efficiency, which is $4.46 \%$. The objective to reduce the use of $\mathrm{Pt}$ in the counter electrode of DSSC is achieved.

\section{Acknowledgment}

This study is supported by the Centre for Research and Instrumentation (CRIM), Universiti Kebangsaan Malaysia and the Ministry of Higher Education Malaysia under Look East Policy (LEP) Grant (LEP 2.0/14/UKM/NT/03/1). We would like to thank the Solar Energy Research Institute (SERI) Colloquium 2015 for providing the platform to the discussion session and disseminating the findings.

\section{References}

1. Karimi, M., Mokhlis, H., Naidu, K., Uddin, S., Bakar, A. H. A. (2016). Photovoltaic penetration issues and impacts in distribution network - a review. Renewable and Sustainable Energy Review, 53: 594 - 605.

2. Hua, Y., Oliphant, M. and Hu, E. J. (2016). Development of renewable energy in Australia and China: A comparison of policies and status. Renewable Energy, 85: 1044 - 1051.

3. Kardooni, R., Yusoff, S. and Kari, F. (2016). Renewable energy technology acceptance in Peninsular Malaysia. Energy Policy, 88: 1 - 10.

4. Smil, V. (1991). General energetics: Energy in the biosphere and civilization. John Wiley: New York, pp. 240.

5. Green, M., Emery, K., Hishikawa, Y., Warta, W. and Dunlop, E. (2015) Solar cell efficiency tables (Version 45). Progress in Photovoltaics Research and Application, 23: 1 - 9

6. Yella, A., Lee, H., Tsao, H., Yi, C., Chandiran, A., Nazeeruddin, M., Diau, E., Yeh, C., Zakeeruddin, S. and Gratzel, M. (2011). Porphyrin-sensitized solar cells with cobalt (II/III)-based redox electrolyte exceed 12 percent efficiency. Science, 334: 629-634.

7. Mathew, S., Yella, A., Gao, P., Humphry-Baker, R., Curchod, B., Ashari-Astani, N., Tavernelli, I., Rothlisberger, U., Nazeeruddin, M. and Gratzel, M. (2014). Dye-sensitized solar cells with $13 \%$ efficiency achieved through the molecular engineering of porphyrin sensitizers. Nature Chemistry, 6: 242 - 247. 
8. Sugaya, T., Numakami, O., Oshima, R., Furue, S., Komaki, H., Amano, T., Matsubara, K., Okano, Y. and Niki, S. (2012). Ultra-high stacks of InGaAs/GaAs quantum dots for high efficiency solar cells. Energy and Environmental Science, 5 (3): 6233 - 6237

9. Yue, G., Lin, J-Y., Tai, S-Y., Xiao, Y. and Wu, J. (2012). A catalytic composite film of $\mathrm{Mos}_{2} /$ graphene flake as a counter electrode for Pt-free dye-sensitized solar cells. Electrochimica Acta, 85: 162 - 168.

10. Wu, J., Lan, Z., Lin, J., Huang, M., Huang, Y., Fan, L. and Luo, G. (2015). Electrolytes in dye-sensitized solar cells. Chemical Reviews, 115(5): $2136-2173$.

11. Guai, G. H., Song, Q. L., Guo, C. X., Lu, Z. S., Chen, T., Ng, C. M. and Li, C. M. (2012). Graphene-Pt/ITO counter electrode to significantly reduce Pt loading and enhance charge transfer for high performance dyesensitized solar cell. Solar Energy, 86: 2041 - 2048.

12. Yun, S., Liu, Y., Zhang, T. and Ahmad, S. (2015). Recent advances in alternative counter electrode materials for Co-mediated dye-sensitized solar cells. Nanoscale, 7: 11877- 11893.

13. Duan, X., Gao, Z., Chang, J., Wu, D., Ma, P., He, J., Xu, F., Gao, S. and Jiang, K. (2013). $\mathrm{CoS}_{2}$-graphene composite as efficient catalytic counter electrode for dye-sensitized solar cell. Electrochimica Acta, 114: 173 179 .

14. Hoshi, H., Tanaka, S. and Miyoshi, T. (2014). Pt-graphene electrodes for dye-sensitized solar cells. Materials Science and Engineering B, 190: 47 - 51.

15. Lipson, H. and Steeple, H. (1970). Interpretation of X-ray powder diffraction pattern. Macmillan, London.

16. Martinson, A. B. F., Goes, M. S., Santiago, F. F., Bisquert, J., Pellin, M. J. and Hupp, J. T. (2009). Electron transport in dye-sensitized solar cells based on $\mathrm{ZnO}$ nanotubes: Evidence for highly efficient charge collection and exceptionally rapid dynamics. Journal of Physical Chemistry A, 113: 4015 - 4021. 